\title{
Morphologic Aspects of Tetratrichomonas didelphidis Isolated from Opossums Didelphis marsupialis and Lutreolina crassicaudata
}

\author{
Tiana Tasca*/++, Geraldo Attilio De Carli/ ${ }^{+}$, Luiz Glock*, \\ Emílio Antônio Jeckel-Neto**
}

Faculdade de Farmácia *Faculdade de Biociências **Instituto de Geriatria e Gerontologia, Pontifícia Universidade Católica do Rio Grande do Sul, Av. Ipiranga 6681, 90619-900 Porto Alegre, RS, Brasil

Tetratrichomonas didelphidis (Hegner \& Ratcliffe, 1927) Andersen \& Reilly, 1965 is a flagellate protozoan found in the intestine, cecum, and colon of Didelphis marsupialis. The parasitic protozoa used in this study was found and isolated in the intestine of opossums in Pavlova starch-containing medium in Florianópolis, State of Santa Catarina, Brazil, from D. marsupialis and Lutreolina crassicaudata. The strains were cultivated in Diamond medium without maltose and with starch solution, $p H 7.5$ at $28^{\circ} \mathrm{C}$. The specimens were stained by the Giemsa method and Heidenhain's iron hematoxylin. The light microscopy study of the trophozoites revealed the same morphologic characteristics as specimens previously described.

Key words: Tetratrichomonas didelphidis - Didelphis marsupialis - Lutreolina crassicaudata - flagellate protozoan - morphology

Tetratrichomonas didelphidis is a parasitic protozoan found in the intestine, cecum and colon of the opossum Didelphis marsupialis. The protozoan is a flagellate belonging to the family Trichomonadidae, subfamily Trichomonadinae (Honigberg 1963). The taxonomy of trichomonads has a complex history. This species was first described by Hegner and Ratcliffe (1927a) under the name Trichomonas didelphidis. Afterwards, Andersen and Reilly (1965) redescribed the species as Tetratrichomonas. To date, there is only one paper on the occurrence and anatomy of trichomonads from opossum $D$. marsupialis. This is the first report on the occurrence of $T$. didelphidis in another opossum species, Lutreolina crassicaudata. Nothing is known about the transmission, epidemiology, pathogenicity, biochemistry and immunologic features, nor about the culture requirements of the parasites.

Many of the cecal trichomonads look alike, and cross-transmission studies have shown that many of them can be easily transmitted from one host

\footnotetext{
This work was supported by Faculdade de Farmácia, Pontifícia Universidade Católica do Rio Grande do Sul. ${ }^{+}$Corresponding author. Fax: +55-51-332.2582. E-mail: gdecarli@portoweb.com.br

${ }^{++}$Research fellow of $\mathrm{CNPq}$

Received 31 March 2000

Accepted 13 November 2000
}

species to another. Further and extensive studies are needed to establish the correct names and host spectra of many trichomonads (Levine 1973).

The aim of this work was to describe the detailed morphology of this trichomonad isolated from D. marsupialis and L. crassicaudata and to compare the data with that of Andersen and Reilly (1965).

\section{MATERIALS AND METHODS}

Isolation - The T. didelphidis strains (TDM86 and TDLC01) used in this study were isolated in Florianópolis, State of Santa Catarina, Brazil by Dr Mário Steindel, in Pavlova starch-containing medium (Pavlova 1938). The TDM86 strain was isolated in the rectal glands from D. marsupialis while the TDLC01 strain was isolated from the swabbed rectum of L. crassicaudata.

Cultivation - Microscopic observation of trichomonads in Pavlova starch-containing media was difficult due to the large quantity of starch granules. Diamond's (1957) modified trypticaseyeast extract-starch (TYS) medium, without maltose and with starch solution $(5 \mathrm{mg} / \mathrm{ml}) \mathrm{pH} 7.5$ (Tasca et al. 1999) supported T. didelphidis growth well. The strains were cultured in vitro at $28^{\circ} \mathrm{C}$ $( \pm 0.5)$ in TYS medium supplemented with $10 \%$ $(\mathrm{v} / \mathrm{v})$ heat inactivated bovine serum, penicilin $(1000$ $\mathrm{UI} / \mathrm{ml})$ and streptomycin sulfate $(1 \mathrm{mg} / \mathrm{ml})$. Isolates were subcultured every $72 \mathrm{~h}$ in TYS starchcontaining media. Certain samples were frozen and maintained at $-196^{\circ} \mathrm{C}$ with $5 \%(\mathrm{v} / \mathrm{v})$ of dimethyl 
sulfoxide (DMSO) as previously described by Honigberg et al. (1965).

Light microscopy - In order to make a comparison with the mensural data given by Andersen and Reilly (1965) the specimens were fixed with methanol and stained by the Giemsa method and Heidenhain's iron hematoxylin (De Carli 1994). Material for the stained smears was obtained from a $72 \mathrm{~h}$ old culture in TYS medium. All measurements were taken from 100 specimens (except when indicated in Table I) using an Olympus AX70 photomicroscope connected to a video camera and to a computer with the Image-Pro Plus 4.1 program. The significance of the variation between the mean measurements of the structures was ana- lyzed using the ANOVA Test. The F values were significant when probability was equal to or lower than 0.05 .

\section{RESULTS}

Microscopic observation of trichomonads from Pavlova's medium was difficult due to the large number of starch granules and bacteria. In this case the flagellates presented numerous vacuoles that distorted the body shape and masked the morphology (Figs 1,2). The vacuoles occupied about $24 \%$ \pm 13.5 (5 to $53 \%$ ) of the entire body area of the protozoa. The organisms grew well in Diamond medium without maltose (TYS) and with starch solution, enabling the morphologic study.

TABLE I

Measurements (in $\mu \mathrm{m}$ ) of Giemsa-stained specimens of Tetratrichomonas didelphidis isolated from opossums Didelphis marsupialis (TDM86) and Lutreolina crassicaudata (TDLC01) and comparisons with data of other authors $(\mathrm{n}=$ number of specimens investigated)

\begin{tabular}{|c|c|c|c|c|}
\hline \multirow[b]{2}{*}{ Structure } & $\begin{array}{l}\text { Andersen \& } \\
\text { Reilly } 1965 \\
n=100\end{array}$ & $\begin{array}{l}\text { Present study, } \\
\text { strain TDM86 } \\
n=100\end{array}$ & $\begin{array}{l}\text { Present study, } \\
\text { strain TDLC01 } \\
\text { n }=100\end{array}$ & $\begin{array}{c}\text { Comparison } \\
\text { between media: } \\
\text { F test }\end{array}$ \\
\hline & \multicolumn{4}{|c|}{ Media \pm standard deviation (variation) } \\
\hline Body length & $\begin{array}{c}6.6 \pm 0.6 \\
(5.6-8.0)\end{array}$ & $\begin{array}{c}7.3 \pm 1.4 \\
(4.2-11.1)\end{array}$ & $\begin{array}{c}7.7 \pm 1.3 \\
(5.1-11.17)\end{array}$ & $22.52^{b}$ \\
\hline Body width & $\begin{array}{l}3.9 \pm 0.4 \\
(2.8-4.8)\end{array}$ & $\begin{array}{l}5.9 \pm 1.4 \\
(2.7-8.8)\end{array}$ & $\begin{array}{c}5.0 \pm 1.2 \\
(3.2-8.8)\end{array}$ & $87.55^{b}$ \\
\hline Nucleus length & $\begin{array}{c}2.9 \pm 0.4 \\
(2.0-4.0)\end{array}$ & $\begin{array}{c}2.7 \pm 0.8 \\
(1.1-4.9)\end{array}$ & $\begin{array}{c}2.5 \pm 0.5 \\
(0,3-3.9)\end{array}$ & $15.12^{b}$ \\
\hline Nucleus width & $\begin{array}{c}2.2 \pm 0.3 \\
(1.6-2.8)\end{array}$ & $\begin{array}{c}2.3 \pm 0.8 \\
(7.4-4.5)\end{array}$ & $\begin{array}{c}1.9 \pm 0.4 \\
(1.1-2.6)\end{array}$ & $20.72^{b}$ \\
\hline Parabasal body length & $\begin{array}{c}1.3 \pm 0.2 \\
(0.8-1.8)\end{array}$ & $\begin{array}{c}1.6 \pm 0.7(\mathrm{a})^{a} \\
(0.9-6.3)\end{array}$ & $\begin{array}{c}1.6 \pm 0.3 \\
(0.8-2.5)\end{array}$ & $14.84^{b}$ \\
\hline Parabasal body width & $\begin{array}{c}1.2 \pm 0.2 \\
(0.8-1.6)\end{array}$ & $\begin{array}{c}1.0 \pm 0.3(\mathrm{~b})^{a} \\
(0.5-2.0)\end{array}$ & $\begin{array}{c}0.9 \pm 0.2 \\
(0,5-1.6)\end{array}$ & $32.10^{b}$ \\
\hline $\begin{array}{r}\text { Anterior flagella } \\
\text { Number } 1\end{array}$ & $\begin{array}{c}17.4 \pm 2.0 \\
(12.0-20.8)\end{array}$ & $\begin{array}{c}18.2 \pm 5.5 \\
(7.5-34.6)\end{array}$ & $\begin{array}{c}15.9 \pm 2.4 \\
(5.2-16.4)\end{array}$ & $9.82^{b}$ \\
\hline Number 2 & $\begin{array}{c}13.5 \pm 1.8 \\
(9.2-17.2)\end{array}$ & $\begin{array}{c}13.3 \pm 2.9 \\
(7.2-21.6)\end{array}$ & $\begin{array}{c}14.5 \pm 2.3 \\
(8.3-17.8)\end{array}$ & $7.82^{b}$ \\
\hline Number 3 & $\begin{array}{c}10.2 \pm 1.7 \\
(6.8-14.8)\end{array}$ & $\begin{array}{c}11.1 \pm 2.7 \\
(5.5-17.8)\end{array}$ & $\begin{array}{c}12.4 \pm 2.2 \\
(9.3-19.2)\end{array}$ & $22.32^{b}$ \\
\hline Number 4 & $\begin{array}{c}7.6 \pm 1.3 \\
(3.6-11.2)\end{array}$ & $\begin{array}{c}8.2 \pm 2.5(\mathrm{c})^{a} \\
(2.6-13.1)\end{array}$ & $\begin{array}{c}10.3 \pm 2.3(\mathrm{f})^{a} \\
(12.1-21.1)\end{array}$ & $44.15^{b}$ \\
\hline Posterior free flagellum & $\begin{array}{c}6.5 \pm 1.3 \\
(3.2-9.2)\end{array}$ & $\begin{array}{c}8.0 \pm 5.8(\mathrm{~d})^{a} \\
(2.1-26.7)\end{array}$ & $\begin{array}{l}4.4 \pm 1.7 \\
(0.4-8.5)\end{array}$ & $28.32^{b}$ \\
\hline Protruding part of axostyle & $\begin{array}{l}4.3 \pm 0.9 \\
(2.4-6.0)\end{array}$ & $\begin{array}{c}4.7 \pm 2.1 \\
(1.0-13.6)\end{array}$ & $\begin{array}{c}2.2 \pm 0.9 \\
(0.2-7.0)\end{array}$ & $94.39^{b}$ \\
\hline Undulating membrane length & - & $\begin{array}{c}12.8 \pm 3.9(\mathrm{e})^{a} \\
(3.1-23.4)\end{array}$ & $\begin{array}{c}17.2 \pm 3.8 \\
(11.0-29.2)\end{array}$ & \\
\hline
\end{tabular}

$a$ : number of specimens different from 100: $(\mathrm{a})=71 ;(\mathrm{b})=71 ;(\mathrm{c})=93 ;(\mathrm{d})=61 ;(\mathrm{e})=77 ;(\mathrm{f})=98 ; b$ : significance level lower than 0.01 
Direct microscopic examination of smears from culture media revealed large numbers of mobile flagellate protozoa. These were classified as trichomonads because of their elongated ellipsoid shape. Accurately counting only became possible when the trichomonads had slowed down or stopped moving. The body is very plastic but not particularly ameboid. Most of these morphological features could be recognized in air-dried smears of culture media fixed in methanol and stained with Giemsa, which produced better results than Heidenhain's iron hematoxylin. Measurements are described in Table I. Trichomonads observed were piriform, whereas living specimens in culture me- dia or stained specimens were usually ellipsoidal, ovoidal, or spheroidal.

There were four anterior flagella unequal in size in the mature individuals (Figs 3, 5). The flagella appear to be applied closely to one another for a short distance anterior to the point at which they emerge from the body. In many permanent preparations they were arranged in two pairs being somewhat longer than the other.

In several specimens a well-developed undulating membrane extended almost the entire length of the body (Figs 3, 6, 7, 8, 9). The undulating membrane often exhibits several bold waves and the outer margin of the membrane consists of the
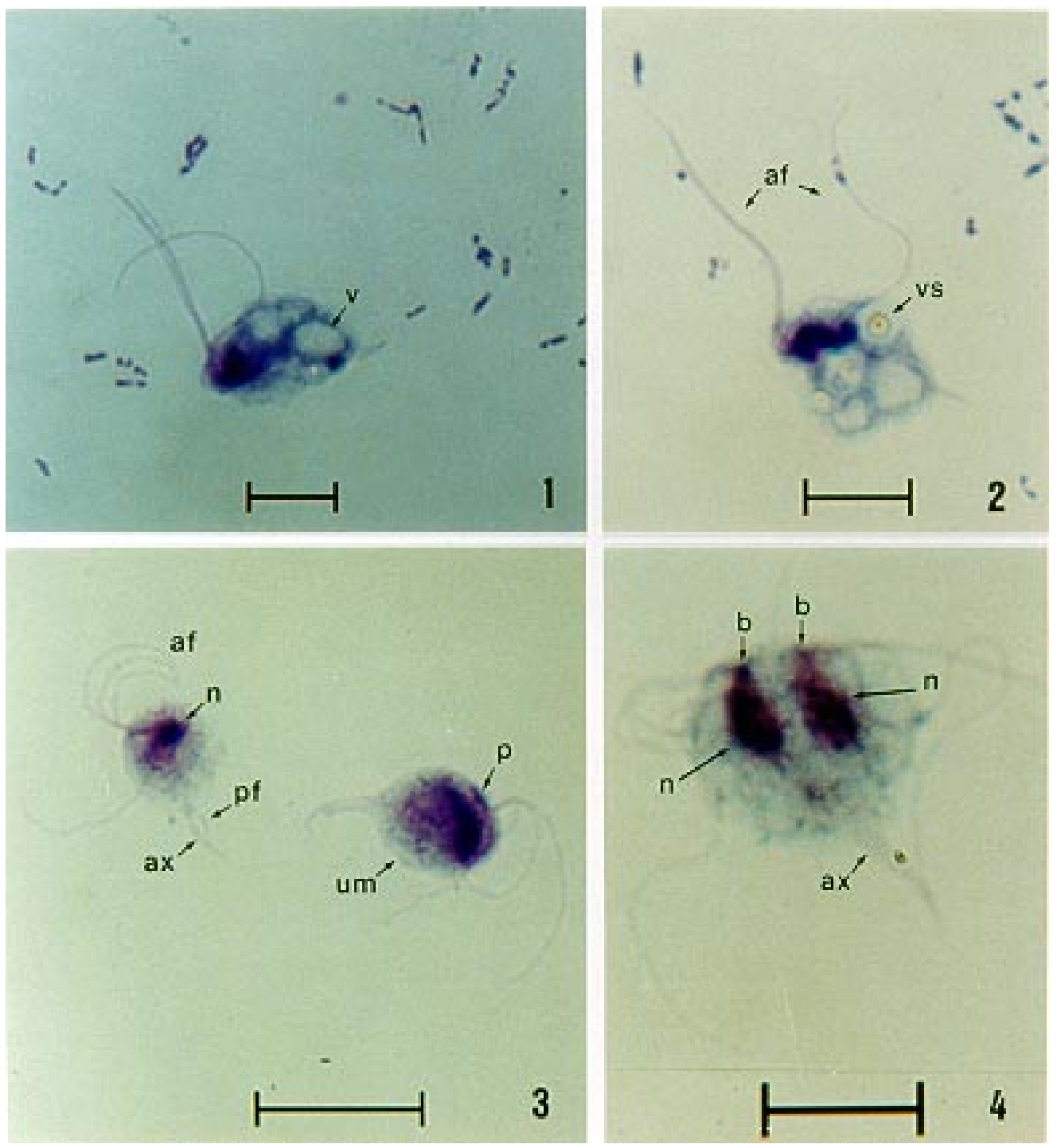

Figs 1-4: morphology of Tetratrichomonas didelphidis, TDM86 strain in Giemsa-stained specimens. Bar = $10 \mu \mathrm{m}$. af: anterior flagella; ax: axostyle; b: blepharoplast; n: nucleus; p: pelta; pf: posterior flagellum; um: undulating membrane; v: vacuoles; vs: vacuoles with starch 
accessory filament, which extends into a free posterior flagellum (Figs 3, 8, 9).

The prominent costa generally extended for the entire length of the body (Figs 6,7). It originated in the area of the blepharoplast but its exact origin was obscured by the parabasal body.

There was a spheroidal, ellipsoidal, or ovoid nucleus situated in the anterior portion of the body (Figs $3,6,7$ ), clearly discernible in most living and stained specimens. The left ventral surface of the nucleus was applied to the spatulate axostylar capitulum. The anterior part of the capitulum was continuous with the pelta, a crescent-shaped membranous structure that surrounds the area of emergence of the anterior flagella from the cell (Figs 3, $6)$. Anterior to the nucleus was a blepharoplast where the flagella were inserted (Fig. 9).

Posterior to the nucleus the capitulum continues as a slender, hyaline, somewhat attenuating axostylar trunk that courses near the anteroposterior axis of the organism, its terminal segment projecting approximately one-third the cell length beyond the posterior surface of the flagellate (Figs 3,8).

The parabasal body was typically disc-shaped with a well-defined constant central granule (Figs $6,8)$.

Figs 4 and 10 show a trophozoite of $T$. didelphidis in binary division.

Comparison between the average structural measurements obtained from our work and the data of Andersen and Reilly (1965) (Table II) revealed that their measurements differed significantly ( $t$ test $>$ 1.96) from those of the TDM86 and TDLC01 strains. There were significant differences ( $t$ test $>$ 1.96) between the TDM86 and TDLC01 strains in nucleus length, nucleus width, parabasal body length, anterior flagella numbers 1, 2 and 3 lengths, posterior free flagellum as well as the protruding part of axostyle length.

\section{DISCUSSION}

There are several species of trichomonads found in domestic animals and man, but nomenclature and host-parasite relations still remain unclear. They have been found in the cecum and colon of almost every species of mammal or bird examined, and they also occur in reptiles, amphibia, fishes, and many invertebrates (Levine 1973).

There are other species belonging to the genus Tetratrichomonas, the type species T. prowazeki, described by Alexeieff (1911), is widely distributed among amphibians and squamate reptiles, in which it inhabits the large intestine.

The most studied species from this genus is $T$. gallinarum. It has worldwide distribution, being harbored by a variety of gallinaceous birds, including chicken, turkey, guinea fowl, quail, and chukar partridge (Bondurant \& Honigberg 1994).

T. anatis, reported by Kotlan (1923) occur in the posterior part of the intestinal tract of domestic ducks and the body is broadly beet-shaped.

Two species were reported by Hegner and Ratcliffe (1927a,b) to occur in the mouths of dogs (T. canistomae) and cats (T. felistomae). The diagnoses of these trichomonads are incomplete, but, as pointed out by Levine (1973), the two organisms actually may belong to a single species.

Hegner and Ratcliffe (1927a) described $T$. macacovaginae from the vagina of a rhesus monkey; T. anseri, was observed by Hegner (1929) in the cecal contents of a domestic goose; T. ovis occurs in the cecum and rumen of domestic sheep (Robertson 1932). T. buttrey was described by Hibler et al. (1960) as occurring in the cecum and colon of pigs and oxen and occasionally in the rumen (cattle) and small intestine (pigs); T. pavlovi was originally described by Pavlov and Dimitrov (1957) as occurring in the large intestine of oxen in Bulgaria, and was named for Pavlov by Levine (1961).

A comparison between the morphology of species of the genus Tetratrichomonas showed that $T$. didelphidis is very similar to the others. All species are found in the intestinal tract in their respective hosts, except $T$. canistomae, $T$. felistomae and T. macacovaginae. Furthermore, the species are probably mutualistic symbiontes; however, there is no satisfactory evidence to suggest that any of the species which inhabit the intestinal tract of their hosts are pathogenic. In the light of the presently available information it appears that the only trichomonad species containing frankly pathogenic strains are found in sites other than the intestine (Honigberg 1963).

The evolution of several genera in the subfamily Trichomonadinae is marked by the increased number of anterior flagella accompanied by differences in the structure of the other mastigont organelles. Two genera, Tetratrichomonas and Trichomitus, may be considered as representing the first evolutionary step. Hence, particularly in actively dividing populations, young organisms with three flagella may be found, and it seems that evolutionary history is repeated in the development of the individual flagellates. Each of the genera is characterized by certain features which they share with Trichomitus (Honigberg 1963).

The genus Tetratrichomonas is different from Trichomonas not only with respect to minor morphological characteristics (parabasal body typically disc-shaped; trunk of axostyle more often slender, relatively stout in some species) but also in the structure of the well-developed undulating membrane, the outer margin of which continues into a 
free posterior flagellum. It is the last attribute which most facilitates the distinction between Trichomitus and Tetratrichomonas on one side and Trichomonas on the other. Although it is nearly impossible to be certain which genera, Tetratrichomonas or Trichomonas, or if both of them, came directly from a Trichomitus-type flagellate, it seems that in most features, morphological as well as physiological

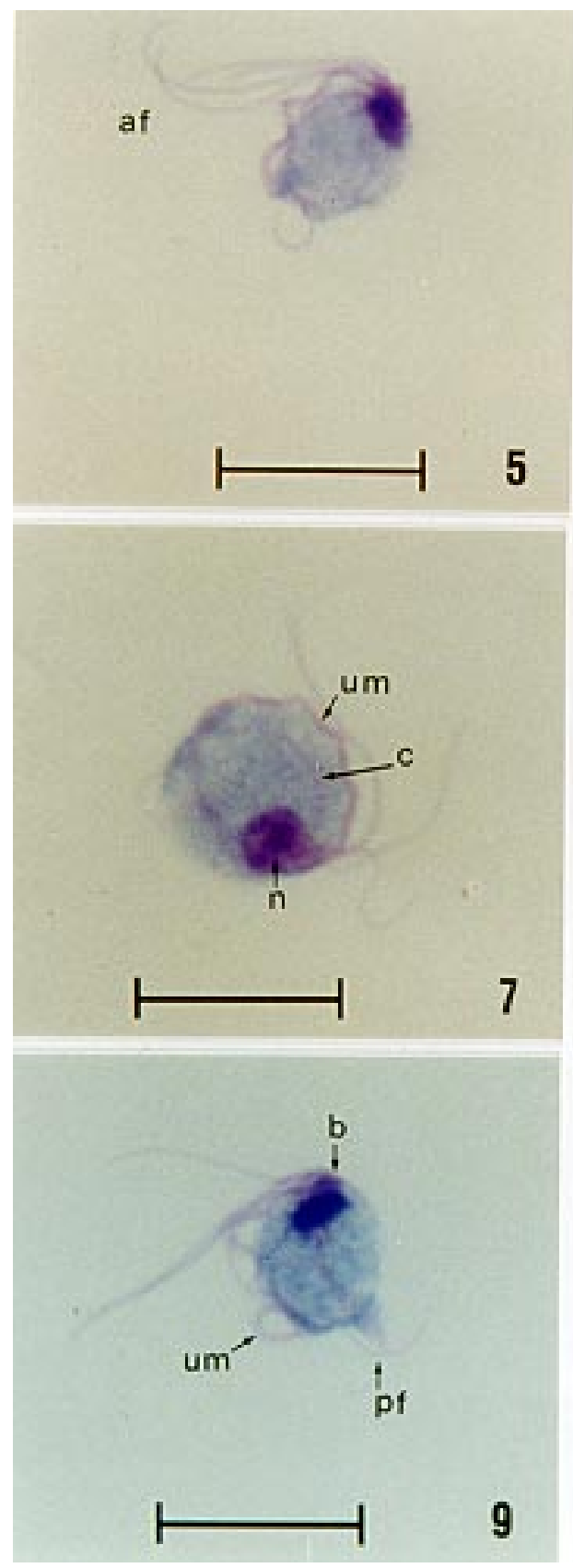

(for example, the primitive site in the hosts), Tetratrichomonas is closer to the main line of evolution (Honigberg 1963). The phylogenetic analysis of $T$. didelphidis is at present, the aim of study of our group.

In the present paper differences were observed between the structural measurements of the TDM86 and TDLC01 strains and the data of
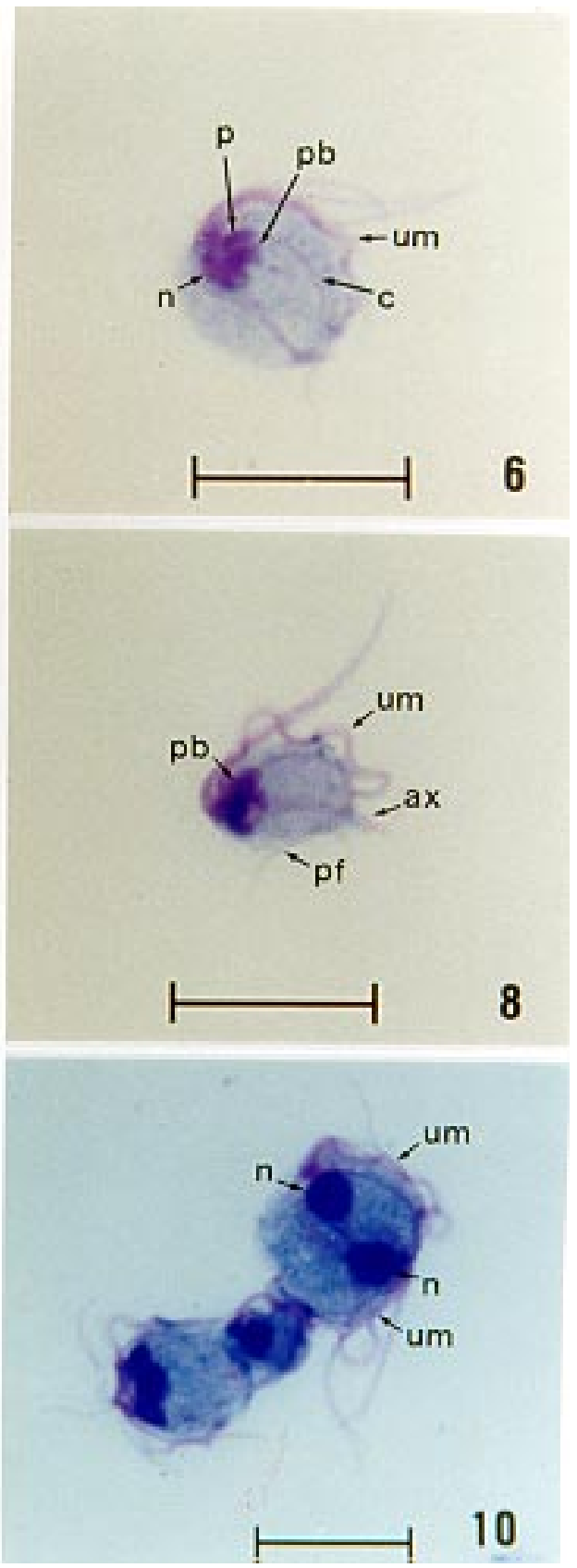

Figs 5-10: morphology of Tetratrichomonas didelphidis, strain TDLC01 in Giemsa-stained specimens. Bar $=10 \mu \mathrm{m}$. af: anterior flagella; ax: axostyle; b: blepharoplast; c: costa; n: nucleus; p: pelta; pb: parabasal body; pf: posterior flagellum; um: undulating membrane 


\section{TABLE II}

Comparison between the different strains of Tetratrichomonas didelphidis isolated from opossums Didelphis

marsupialis (TDM86) and Lutreolina crassicaudata (TDLC01) and data of other authors by Post Hoc Test

\begin{tabular}{|c|c|c|c|c|c|c|}
\hline \multirow[b]{2}{*}{ Structure } & \multicolumn{2}{|c|}{$\begin{array}{l}\text { Andersen \& } \\
\text { Reilly } 1965\end{array}$} & \multicolumn{2}{|c|}{$\begin{array}{l}\text { Present study, } \\
\text { strain TDM86 }\end{array}$} & \multicolumn{2}{|c|}{$\begin{array}{l}\text { Present study, } \\
\text { strain TDLC01 }\end{array}$} \\
\hline & $\begin{array}{c}\text { Strain } \\
\text { TDM86 }\end{array}$ & $\begin{array}{c}\text { Strain } \\
\text { TDLC01 }\end{array}$ & $\begin{array}{l}\text { Andersen \& } \\
\text { Reilly } 1965\end{array}$ & $\begin{array}{c}\text { Strain } \\
\text { TDLC01 }\end{array}$ & $\begin{array}{c}\text { Strain } \\
\text { TDM86 }\end{array}$ & $\begin{array}{l}\text { Andersen \& } \\
\text { Reilly } 1965\end{array}$ \\
\hline Body length & $8.81^{a}$ & $2.85^{a}$ & $8.81^{a}$ & 1.45 & 1.45 & $2.85^{a}$ \\
\hline Body width & $11.49^{a}$ & $2.94^{a}$ & $11.49^{a}$ & 1.89 & 1.89 & $2.94^{a}$ \\
\hline Nucleus length & $10.40^{a}$ & $9.38^{a}$ & $10.40^{a}$ & $6.45^{a}$ & $6.45^{a}$ & $9.38^{a}$ \\
\hline Nucleus width & $13.49^{a}$ & $12.52^{a}$ & $13.49^{a}$ & $11.49^{a}$ & $11.49^{a}$ & $12.52^{a}$ \\
\hline Parabasal body length & $13.54^{a}$ & $7.10^{a}$ & $13.54^{a}$ & $8.73^{a}$ & $8.73^{a}$ & $7.10^{a}$ \\
\hline Parabasal body width & $3.36^{a}$ & $2.56^{a}$ & $3.36^{a}$ & 0.95 & 0.95 & $2.56^{a}$ \\
\hline $\begin{array}{r}\text { Anterior flagella } \\
\text { Number } 1 \\
\text { Number } 2 \\
\text { Number } 3 \\
\text { Number } 4\end{array}$ & $\begin{array}{r}11.89^{a} \\
6.49^{a} \\
6.27^{a} \\
8.54^{a}\end{array}$ & $\begin{array}{l}1.91 \\
2.62^{a} \\
4.43^{a} \\
8.09^{a}\end{array}$ & $\begin{array}{r}11.89^{a} \\
6.49^{a} \\
6.27^{a} \\
8.54^{a}\end{array}$ & $\begin{array}{r}10.69^{a} \\
4.07^{a} \\
2.02^{a} \\
0.62\end{array}$ & $\begin{array}{c}10.69^{a} \\
4.07^{a} \\
2.02^{a} \\
0.62\end{array}$ & $\begin{array}{l}1.91 \\
2.62^{a} \\
4.43^{a} \\
8.09^{a}\end{array}$ \\
\hline Posterior free flagellum & $15.37^{a}$ & $3.89^{a}$ & $15.37^{a}$ & $13.54^{a}$ & $13.54^{a}$ & $3.89^{a}$ \\
\hline Protruding part of axostyle & $10.37^{a}$ & 0.31 & $10.37^{a}$ & $10.15^{a}$ & $10.15^{a}$ & 0.31 \\
\hline Undulating membrane length & - & - & - & 0.65 & 0.65 & - \\
\hline
\end{tabular}

a: significance level lower than 0.01

Andersen and Reilly (1965). When compared the microphotographs of those authors and the present work, it seems to be the same flagellate protozoa in both studies. The discrepancy between the measurements observed was probably due to the different types of fixatives and stains. Often the shape of trichomonads is variable in fresh and in fixed and stained preparations. Physicochemical conditions (e.g., $\mathrm{pH}$, temperature, oxygen tension, and ionic strength) affect the shape of trichomonads (Honigberg \& Brugerolle 1990). In the present study the measured specimens were fixed in methanol and stained with the Giemsa method, while Andersen and Reilly (1965) used the protargol stain. Furthermore, the differences between the TDM86 and TDLC01 strains and the data of Andersen and Reilly (1965) is due to sample variation and the measurements could not be used as a systematic criterion.

Finally, in the present investigation it was observed that $T$. didelphidis found in the intestine content of opossums D. marsupialis and $L$. crassicaudata had the same morphological characteristics as those previously described by Andersen and Reilly (1965) in D. marsupialis, being the same protozoan species in both different host species.

\section{ACKNOWLEDGMENTS}

To Dr Sérgio De Meda Lamb Pharmacy School Chairman. To Miss Rossana Mattia (Fapergs), Iveli Rosset (BPA-PUCRS), Márcia C Andreazza, Mr Marcos Colombo and Gilson José de Oliveira for technical support.

\section{REFERENCES}

Alexeieff AG 1911. Sur la spécification dans le genre Trichomonas Donné. Compt Rend Soc Biol 71: 539541.

Andersen FL, Reilly JR 1965. The anatomy of Tetratrichomonas didelphidis (Hegner and Ratcliffe, 1927) comb. nov. from the opossum. J Parasitol 14: 27-35.

Bondurant RH, Honigberg BM 1994. Trichomonads of veterinary importance. In JP Kreier, Parasitic Protozoa, Academic Press, New York, p. 111-204.

De Carli GA 1994. Diagnóstico Laboratorial das Parasitoses Humanas. Métodos e Técnicas, MEDSI, Rio de Janeiro, $315 \mathrm{pp}$.

Diamond LS 1957. The establishment of various trichomonads of animals and man in axenic cultures. $J$ Parasitol 43: 488-490.

Hegner RW 1929. The infection of parasite-free chicks with intestinal, protozoa from birds and other animals. Am J Hyg 10: 33-62.

Hegner RW, Ratcliffe H 1927a. Trichomonads from the vagina of the monkey, from the mouth of the cat and man, and from the intestine of the monkey, opos- 
sum and prairie-dog. J Parasitol 14: 27-35.

Hegner RW, Ratcliffe H 1927b. Trichomonads from the mouth of the dog. J Parasitol 14: 51-53.

Hibler CP, Hammond DM, Caskey FH, Johnson AE, Fitzgerald PR 1960. The morphology and incidence of the trichomonads of swine, Tritrichomonas suis (Gruby \& Delafond), Tritrichomonas rotunda, n. sp. and Trichomonas buttreyi, n. sp. J Protozool 7: 159171.

Honigberg BM 1963. Evolutionary and systematic relationships in the flagellate order Trichomonadida Kirby. J Protozool 10: 20-63.

Honigberg BM, Brugerolle G 1990. Structure. In BM Honigberg, Trichomonads Parasitics in Humans, Springer-Verlag, New York, p. 5-35.

Honigberg BM, Faris VK, Livingston MC 1965. Preservation of Trichomonas vaginalis and Trichomonas gallinae in liquid nitrogen. Prog. Protozool, Int Conf Protozool, 2nd Excerpta Mod Found Int Congr Ser No 91, p. 199.

Kotlan AS 1923. Zur kentniss der darmflagellaten aus der hausente und anderen wassrvogeln. Zentralbl
Bakteriol Parasitenkd Infektionskr Hvg 90: 24-28. Levine ND 1961. Protozoan Parasites of Domestic Animals and of Man, Burgess Publishing Co., Minnesota, $406 \mathrm{pp}$.

Levine ND 1973. The Trichomonads. In Protozoan Parasites of Domestic Animals and of Man, 2nd ed., Burgess Publishing Co., Minnesota, p. 88-110.

Pavlova EA 1938. Sur les méthodes de la culture d' Entamoeba histolytica. Med Parazitol 7: 224-227.

Pavlov P, Dimitrov S 1957. Ueber eine neue Trichomonas art bewi Kalbern, Trichomonas bovis sp.n. Zentralbl Bakteriol Parasitenkd Infektionskr Hvg 168: 293-297.

Robertson A 1932. Note on a Trichomonas sp. cultivated from the gut of a sheep, Ditrichomonas ovis (nov. sp.). Vet J 88: 151-157.

Tasca T, De Carli GA, Steindel M, Mattia R, Rosset I 1999. Modification and adaptation in semi-defined media for cultivation of flagellate Tetratrichomonas didelphidis (Trichomonadidae: Trichomonadinae) from the Didelphis marsupialis. Parasitol al Dia 23: 121-122. 